The Ring-billed Gull colony appeared to contain complete clutches, although no young had yet hatched. Their nests contain "usually hree, sometimes two, very rarely our" eggs." Sixty-two of these Ringbilled Gull nests contained four eggs, eight had five eggs and one had six eggs. The remaining gull nests had the usual three. Numbers of fourand five-egg clutches appear significant because they infer a larger han normal clutch size rather than he pairing of two females.

Other Ring-billed Gull colonies surveyed in 1979 contained abnormal clutch sizes, but none approached the proportion focumented on the Bachelor's Island folony.

HARRISON, COLIN. 1978. A field guide to the nests, eggs and nestlings of North American birds. Collins, New York. 416 pp.

\section{BALD EAGLE NEST IN A MANITOBA HERON COLONY}

W. H. KOONZ, Manitoba Dept. of Natural Resources, 1495 St. James Street, Winnipeg, Manitoba.

On 19 June 1979, while making an herial census of a Great Blue Heron colony on one of Lake Winnipegosis' Sister Islands $\left(52^{\circ} 25^{\prime} \mathrm{N}, 99^{\circ} 46^{\prime} \mathrm{W}\right)$, wo observers and I saw two adult Bald Eagles close to a nest containng two young eagles. The nest was hear the top of the island's largest ree, a dead balsam poplar (Populus palsamifera). I did not see any active peron nests in that tree although here were 30 or more active nests in surrounding trees, some at a disance of $10 \mathrm{~m}$ or less. The eaglets were several weeks old while heron chicks were just beginning to hatch.

The observation is of interest and worthy of future field observation to determine if the two species will coexist in such close proximity. The abandonment of a heron colony at Beaver Lake $\left(54^{\circ} 43^{\prime} \mathrm{N}, 111^{\circ} 53^{\prime} \mathrm{W}\right)$ between 1970 and 1972 supposedly due to the establishment of an eagle nest in the colony was reported by Vermeer (Can. Field Nat. 87:427432).

\section{EAGLE/COYOTE INCIDENT}

SIG JORDHEIM, White Bear, Saskatchewan, SOL 3LO.

On 25 November 1979, I was on a hill overlooking Lake Diefenbaker. At this late date there were still several hundred Canada Geese and Mallard ducks on about an acre of open water toward the south shore of the lake.

I noticed a gathering of eagles on a small island close to the north shore. Through 16X binoculars I noted that one Golden Eagle was feeding on a Canada Goose, and four others were gathered around, hoping to get something for themselves. While they seemed to respect the feeding eagle, they were constantly harassing each other; at one time two of them came to grips and thrashed wildly for a moment until one got free and gave ground.

Then I saw a coyote trotting briskly toward the gathered eagles, coming across the ice from the south side. On getting closer it broke into a lope, then on reaching the island, with head lowered, hackles up and tail swinging from side to side it charged directly at the eagles. 
The four that had no prey took to the air, but not the one with the goose. When the coyote was quite close, the eagle jumped right at it, and from my vantage point, it looked as if it actually grabbed the coyote. There was a lot of action for a brief moment; the eagle with flailing wings and the coyote struggling to get back in the direction he had come from.

Suddenly the coyote dashed around the eagle and made a rush for the goose, but before he could pick it up, the eagle again attacked and the coyote jumped out of reach.

Now the eagle remained on the goose carcass and resumed eating as if nothing had happened. The coyote meanwhile circled the feeding bird at a distance of perhaps eight feet. Once he tried to sneak up behind and grab something, but immediately the eagle turned and struck out with his feet and the coyote hastily retreated.

Eventually he lay down some 30 feet from the eagle and waited. In about a half-hour the big bird had his fill and flew away. Immediately the coyote picked up the remains of the goose and trotted back to the south side and there stopped to eat.

\section{CARDINAL AT PIKE LAKE, SASKATCHEWAN}

STANLEY J. SHADICK, 810 Main Street, Saskatoon, Saskatchewan, S7H OK3.

On 14 October 1979, the Saskatoon Natural History Society's Rare Bird Alert sprang into action and reported two rare sightings. $A$ farmer near Warman had spotted three Whooping Cranes. Meanwhile at Pike Lake, Laura Hoyte reported that a male Cardinal had bee regularly visiting her bird feeder. Tw rare birds in one day presented dilemma - which bird should on look for? The only reasonabl solution - look for both. Tha afternoon I drove out to the Warma district with my parents and foun several SNHS members looking fo the Whooping Cranes. After a hour's search we found them behin a hill. After viewing the whoopers, w continued on to Pike Lake. Te minutes after arriving we wer delighted to find the Cardinal emerg from the bushes and feed on th ground with some juncos.

The Cardinal had first bee spotted in the area as early as lat July by the Hoytes' neighbours, Mr and Mrs. Bell. However, the Cardine was then very elusive and was see only occasionally until mid-Octobe From 14-27 October, it visite Hoyte's feeder regularly. During thi period it was observed by man members of the Saskatoon NHS Stuart and Mary Houston attempte to trap the bird for banding purpose but were unsuccessful. Lawrenc Baschak was able to obtain sever photographs.

The only previous record for th Saskatoon district was a Cardine observed by Frank Roy and party 0 the May Day Count, 26 May 195 (Blue Jay, 15:102). Other Saskat chewan observations were mad east of Yorkton by $\mathrm{P}$. Fraser in $\mathrm{Ma}$ 1895 (Blue Jay, 19:142), in Regina b F. G. Bard during summer 1926, i Esterhazy by Mrs. Bert Ford durin January 1951 and at the farm hom of Mrs. Ted Scriven on 9 July 195 (Blue Jay, 19:77). The last report i Saskatchewan was a male collecte at Craven by R. W. Nero and Elme Fox on 29 December 1960 (ibid). Th Pike Lake observation therefor represents the only Saskatchewa report during the last 19 years. 